\title{
Minat Memesan Kembali Jasa Transportasi Online
}

Jovi Iristian

Fakultas Ekonomi dan Bisnis, Universitas Dr. Soetomo Surabaya

joviiristian@unitomo.ac.id

\begin{abstract}
Abstrak
Jumlah pengguna smartphone yang terus meningkat sesekali. dengan semakin banyaknya akses ke layanan transportasi online dari web dan aplikasi. Teknologi yang dikembangkan dengan memahami pengalaman pengguna telah mengubah perilaku orang saat bepergian dan kegiatan sehari-hari. Aplikasi pemesanan kendaraan merupakan terobosan terutama karena menyediakan sistem pengumpulan dan pengiriman yang nyaman dengan harga terjangkau. Tujuan dari penelitian ini adalah untuk mengetahui pengalaman merek, keterkaitan emosional pada merek dan citra merek terhadap minat memesan kembali jasa transportasi online. Populasi adalah pelanggan pengguna jasa transportasi online "Grab". Penelitian ini menggunakan 150 sampel responden dengan kriteria telah menggunakan layanan jasa transportasi online lebih dari dua kali. Kemudian data dianalisis memakai analisis regresi berganda yang diolah menggunakan program SPSS versi 21. Berdasarkan hasil penelitian, hasil bahwa pengalaman merek dan keterkaitan emosional pada merek berpengaruh signifikan terhadap minat memesan kembali jasa transportasi online Grab, sedangkan citra merek berpengaruh tidak signifikan terhadap minat memesan kembali jasa transportasi online Grab. Dengan variabel pengalaman merek, keterkaitan emosional pada merek dan citra merek terhadap minat memesan kembali jasa transportasi online Grab di Surabaya sebesar $41,5 \%$ dan selebihnya dijelaskan oleh faktor lain yang tidak dijelaskan dalam model regresi yang diperoleh.
\end{abstract}

\section{Kata Kunci : Pengalaman Merek, Keterkaitan Emosional Pada Merek, Citra Merek, Minat Memesan Kembali}

\begin{abstract}
The number of smartphone users that continues to increase over time seems to be in line with the increasing number of users of online transportation services from the web and applications. Technology that is built by understanding the experience of its users has changed people's behavior in traveling and carrying out daily activities. The vehicle booking application in particular has been a breakthrough because it allows a convenient pick-up and delivery system at an affordable price. The purpose of this study was to determine brand experience, emotional connection to the brand and brand image to interest in ordering back online transportation services. The population is customers who use the online transportation service "Grab". This study uses 150 samples of respondents with the criteria of using online transportation services more than twice. Then the data were analyzed using multiple regression analysis which was channeled through the SPSS 21 program. Based on the results of the study, the results that brand experience and emotional connection to the brand have a significant effect on the interest in
\end{abstract}


ordering Grab's online transportation services, while the brand image has no significant effect on the interest in ordering Grab's online transportation services. With the variable brand experience, emotional linkages to the brand and brand image to interest in re-ordering Grab online transportation services in Surabaya amounted to $41.5 \%$ and the rest explained by other factors not explained in the regression model obtained.

Keywords: Brand Experience, Emotional Linkages to Brands, Brand Image, Re-Order Interest

\section{PENDAHULUAN}

Tampaknya peningkatan jumlah pengguna smartphone seiring waktu sejalan dengan peningkatan jumlah pengguna layanan transportasi online dari web dan aplikasi. iPrice mengatakan bahwa rata-rata peningkatan kunjungan seluler di kawasan Asia-Pasifik mencapai sembilan belas persen dalam setahun terakhir. Sementara berdasarkan sampel dari 2018, data TECHINASIA dari ecommerce di negara itu menunjukkan rata-rata 87 persen dari kunjungan yang dilakukan dari penggunaan perangkat seluler. Temuan ini semakin membuktikan bahwa pangsa pengguna ponsel adalah potensi yang signifikan dalam jumlah kunjungan yang lebih besar.

Salah satunya, Grab (sebelumnya dikenal sebagai GrabTaxi), adalah salah satu platform berbasis $\mathrm{O} 2 \mathrm{O}$ di Singapura dan paling umum digunakan di Asia Tenggara, menyediakan pelanggan dengan kebutuhan sehari-hari seperti perjalanan, pengiriman makanan, pengiriman dan pembayaran. Saat ini, Grab menyediakan layanan di Singapura, Indonesia, Filipina, Malaysia, Thailand, Vietnam, Myanmar, dan Kamboja. Grab percaya bahwa setiap komunitas di Asia Tenggara harus mendapat manfaat dari ekonomi digital, dan perusahaan menyediakan akses ke layanan transportasi yang aman dan terjangkau, layanan pengiriman pesan antara pengiriman makanan dan barang, dan layanan pembayaran mobile dan keuangan. Grab juga merupakan "decacorn" (titik awal yang memiliki valuasi \$ 10 miliar atau 10 kali lebih banyak dari "unicorn") di Asia Tenggara.

Berdasarkan pengalaman pengguna dalam penggunaan aplikasi, harus diakui bahwa aplikasi Grab relatif lancar dan memiliki kesalahan kecil Go-Jek. Selain itu, Grab memiliki fitur panggilan dan panggilan telepon dalam aplikasi. Oleh karena itu, tidak perlu biaya tambahan (pelaut yang terhubung) ketika perlu mengundang atau mengirim teks karena didasarkan pada data Internet. Komunikasi ini memungkinkan pengemudi dan pelancong untuk tidak mengetahui nomor telepon, sehingga privasi tetap terjaga. Grab juga mencantumkan nomor lisensi kendaraan pengemudi pada aplikasi tersebut, sehingga memudahkan penumpang untuk menemukan pengemudi yang mengunduh kendaraan tersebut. Di sisi lain, rata-rata pengemudi Grab juga agak lebih disiplin menggunakan seragam sebagai salah satu identitasnya. Inilah yang membuat konsumen puas, sehingga pengalaman menggunakan layanan transportasi Grab tertanam dalam kesadaran konsumen.

Menurut Brakus, Schmitt dan Zarantonell (2009), Pengalaman Merek didefinisikan sebagai sensasi, perasaan, kognisi dan reaksi merek konsumen yang berkaitan dengan rangsangan yang disebabkan oleh desain merek, identitas merek, komunikasi pemasaran, orang dan lingkungan di 
mana merek dijual. Selain pengalaman, emosi konsumen juga mempengaruhi pengalihan layanan yang mereka inginkan. Pada dasarnya, pemasaran emosional adalah upaya untuk menyampaikan pesan yang dapat membangun ego Anda dan membuat Anda merasa lebih baik sebagai konsumen. Sepertinya Anda lebih pintar, lebih terang, lebih canggih atau lebih. Pemasaran emosional juga berguna untuk membuat produk yang lebih menonjol daripada produk lainnya. Dapat dikatakan bahwa keterikatan emosional terhadap suatu merek adalah keterikatan emosional antara konsumen yang ditandai oleh perasaan yang mendalam akan keterikatan, keterikatan, dan hasrat untuk merek tertentu yang mereka konsumsi.

Minat emosional pada merek juga berasal dari citra merek merek tersebut. Layanan yang baik akan memperkuat citra merek dan dapat diandalkan serta diandalkan oleh konsumen. Citra merek mewakili representasi persepsi keseluruhan merek dan dibentuk dari informasi dan pengalaman masa lalu tentang merek ini. Citra merek mengacu pada sikap dalam bentuk kepercayaan dan preferensi merek. Konsumen yang memiliki citra positif terhadap merek akan lebih cenderung membeli. Setiadi (2003) mengklaim bahwa citra merek mengacu pada skema memori merek, yang berisi interpretasi atribut konsumen, keuntungan, penggunaan, situasi, pengguna dan karakteristik pemasar dan / atau karakteristik produk / merek. Citra positif konsumen terhadap merek memungkinkan konsumen untuk membeli. Merek yang lebih baik juga merupakan dasar untuk membangun citra perusahaan yang positif.

Pengalaman merek, pencitraan emosional merek dan citra merek adalah tiga hal yang dapat mendorong konsumen / pelanggan untuk membeli kembali. Pembelian ulang menurut penelitian Nurhayati dan Wahyu (2012: 53) adalah kemauan dan tindakan konsumen untuk membeli produk, karena kepuasan yang mereka terima sesuai dengan produk yang diinginkan. Merek yang melekat pada hati pelanggan akan menyebabkan pembeli terus membeli atau membeli. Berdasarkan latar belakang, tujuan dari penelitian ini adalah untuk mengetahui seberapa besar minat memesan ulang Grab dilihat dari pengalaman merek, ikatan emosional dengan merek dan citra mereka.

\section{METODOLOGI PENELITIAN}

Penelitian ini adalah jenis penelitian asosiatif. Penelitian asosiatif adalah penelitian yang bertujuan menentukan hubungan antara dua atau lebih variabel (Sugiyono, 2009: 11). Populasi dalam penelitian ini adalah konsumen yang menggunakan layanan transportasi online di Surabaya. Menentukan jumlah sampel yang mewakili tergantung pada jumlah indikator yang dikalikan 5-10 (Hair, 2006). Jumlah indikator dalam penelitian ini adalah 15 dan dikalikan dengan 10, sehingga sampel dalam penelitian ini adalah 150.

Dalam penelitian ini, alat analisis digunakan, sebagai berikut: a) Uji Validitas. Tes validasi adalah ukuran yang menunjukkan seberapa banyak alat ukur mampu mengukur apa yang ingin Anda ukur. Tingkat validitas dapat diukur dengan membandingkan nilai yang dihitung $\mathrm{r}$ (korelasi dari total korelasi) dengan nilai tabel $r$ dengan ketentuan untuk derajat kebebasan $(\mathrm{df})=\mathrm{nk}$, di mana $\mathrm{n}$ adalah jumlah sampel dan $\mathrm{k}$ adalah jumlah variabel independen. Kriteria validasi untuk uji validasi adalah: $r$ hitung $>r$ tabel, maka pernyataan tersebut valid $r$ hitung $<r$ tabel, maka pernyataan tersebut tidak valid. b) Uji reliabilitas. Instrumen yang dapat diandalkan adalah 
ukuran instrumen yang menunjukkan konsistensi instrumen pengukur dalam mengukur gejala yang sama pada kesempatan lain. Hasilnya ditunjukkan oleh indeks yang menunjukkan seberapa andal atau andalnya alat ukur itu. Konstruk dikatakan dapat diandalkan jika memiliki nilai cronbach alpha $>0,6$.

Asumsi uji klasik dilakukan bersamaan dengan proses uji regresi. Asumsi uji klasik dikatakan baik jika memenuhi asumsi uji klasik yang melibatkan normalitas, multikolineritas, dan heteroskedastisitas. Analisis regresi linier berganda digunakan untuk mengetahui pengaruh dua atau lebih variabel independen dengan satu variabel dependen yang ditampilkan dalam bentuk persamaan regresi. Variabel independen diwakili oleh $\mathrm{X} 1, \mathrm{X} 2, \mathrm{X} 3 \ldots \mathrm{Xn}$ sedangkan variabel dependen diwakili oleh Y (Priyatno 2011: 238).

Dengan menguji hipotesis yang diajukan, yitu uji $\mathrm{T}$ dan uji $\mathrm{F}$. Uji t adalah pengujian pada variabel independen secara parsial, sedangkan uji f menguji pengaruh variabel independen secara simultan atau bersama-sama. Penentuan determinasi digunakan untuk menentukan persentase kontribusi pengaruh variabel independen secara bersama-sama terhadap variabel dependen (Priyatno 2011: 251).

\section{HASIL DAN PEMBAHASAN}

Uji Validitas. Semua item pertanyaan (indikator) pada semua variabel penelitian menghasilkan nilai-nilai yang dikoreksi dari total korelasi item yang lebih besar dari $r$ tabel, sehingga dapat dikatakan bahwa pernyataan pernyataan yang mengukur setiap variabel penelitian dapat dinyatakan valid.

Uji Reliabilitas. Diketahui bahwa nilai cronbach's_alpha pada setiap nilai variabel penelitian lebih besar dari 0,60, sehingga pernyataan yang mengukur variabel penelitian dengan persyaratan reliabilitas atau keandalan kuesioner.

Uji Multikolinearitas. Hasil tes menunjukkan bahwa semua variabel yang digunakan sebagai model regresi menunjukkan nilai VIF yang relatif kecil, di mana semuanya di bawah 10, dan nilai toleransi lebih dari 0,1 . Ini berarti bahwa variabel independen yang digunakan dalam penelitian ini tidak menunjukkan gejala multikolinieritas, yang berarti bahwa semua variabel ini dapat digunakan sebagai variabel yang saling independen..

Uji Heteroskedastisitas. Hasil dari uji heteroskedastisitas menunjukkan bahwa tidak ada pola yang jelas dari poin-poin ini. Ini menunjukkan bahwa model regresi tidak memiliki gejala heteroskedastisitas, yang berarti bahwa tidak ada gangguan signifikan dalam model regresi ini..

Uji Normalitas. Hasil uji normalitas menunjukkan bahwa mereka terdistribusi normal, sebagaimana dibuktikan oleh bentuk simetris yang tidak miring ke kanan atau kiri. Menguji hipotesis

Analisa Regresi Linear Berganda. Berikut ini adalah hasil pengolahan data menggunakan analisa regresi linear berganda untuk mengetahui hubungan antara pengalaman merek, keterkaitan 
emosional pada merek dan citra merek terhadap niat memesan kembali Grab di Surabaya. Pengolahan data menggunakan program SPSS 21.0

Tabel 1. Hasil Regresi Linier Berganda Coefficients $^{\mathrm{a}}$

\begin{tabular}{|c|c|c|c|c|c|c|c|c|}
\hline \multicolumn{2}{|c|}{ Model } & \multicolumn{2}{|c|}{$\begin{array}{c}\text { Unstandardized } \\
\text { Coefficients }\end{array}$} & \multirow{2}{*}{$\begin{array}{c}\begin{array}{c}\text { Standardized } \\
\text { Coefficients }\end{array} \\
\text { Beta } \\
\end{array}$} & \multirow[t]{2}{*}{$t$} & \multirow[t]{2}{*}{ Sig. } & \multicolumn{2}{|c|}{$\begin{array}{c}\text { Collinearity } \\
\text { Statistics }\end{array}$} \\
\hline \multirow{5}{*}{1} & & B & Std. Error & & & & Tolerance & VIF \\
\hline & (Constant) & $-16,565$ & 8,625 & & $-1,921$ & 0,059 & & \\
\hline & JML PM &,- 635 & 0,319 & $-0,181$ & $-1,990$ & 0,050 & 0,993 & 1,007 \\
\hline & JML KE & 2,066 & 0,317 & 0,596 & 6,518 & 0,000 & 0,987 & 1,014 \\
\hline & JML CM & 0,639 & 0,373 & 0,156 & 1,711 & 0,091 & 0,986 & 1,015 \\
\hline
\end{tabular}

a. Dependent Variable: JML MU

Sumber : Data Diolah SPSS 21.0 (2019)

Berdasarkan tabel 1 apabila ditulis persamaan regresi dalam bentuk standardized coefficient sebagai berikut : $\mathrm{Y}=-0,181 \mathrm{X} 1+0,596 \mathrm{X} 2+0,156 \mathrm{X} 3$

Dari hasil analisis regresi diatas dapat dilihat variabel keterkaitan emosional pada merek memiliki pengaruh yang paling besar terhadap niat memesan kembali Grab di Surabaya, kemudian diikuti dengan variabel pengalaman merek dan citra merek.

Uji Signifikansi Parameter Individual (Uji t). Berdasarkan tabel 1 diatas, hasil uji t dapat dilihat bahwa variabel pengalaman merek dan keterkaitan emosional pada merek yang mempengaruhi niat memesan kembali Grab di Surabaya. Sedangkan variabel citra merek tidak mempengaruhi niat memesan kembali Grab di Surabaya karena nilai signifikannya diatas 0,05.

\begin{tabular}{|c|c|c|c|c|c|c|}
\hline \multicolumn{7}{|c|}{$\begin{array}{c}\text { Tabel 2. Hasil Uji F } \\
\text { ANOVA }^{\mathrm{a}}\end{array}$} \\
\hline Model & & Sum of & & Mean & $\mathrm{F}$ & Sig. \\
\hline \multirow{3}{*}{1} & Regression & 1090,282 & 3 & 363,427 & 16,780 &, $000^{b}$ \\
\hline & Residual & 1537,718 & 71 & 21,658 & & \\
\hline & Total & 2628,000 & 74 & & & \\
\hline
\end{tabular}

a. Dependent Variable: JML MU

b. Predictors: (Constant), JML CM, JML PM, JML KE

Sumber : Data Diolah SPSS 21.0 (2019)

Uji F digunakan untuk melakukan pengujian variabel bebas secara bersama-sama terhadap variabel terikatnya. Berdasarkan hasil uji $\mathrm{F}$ yang telah dilakukan didapatkan nilai $\mathrm{F}$ sebesar 16,780 dengan tingkat signifikansi 0,000. Nilai signifikansi lebih kecil dari 0,05 maka dapat diketahui variabel independent yang digunakan layak digunakan untuk menguji variabel dependent niat memesan kembali. 
Tabel 3. Hasil Koefisien Determinasi (R2) Model Summary ${ }^{b}$

\begin{tabular}{lcrrr}
\hline Model & $\mathrm{R}$ & R Square & Adjusted R Square & Std. Error of the Estimate \\
\hline 1 & $0,644^{\mathrm{a}}$ & 0,415 & 0,390 & 4,65381 \\
\hline
\end{tabular}

a. Predictors: (Constant), JML CM, JML PM, JML KE

b. Dependent Variable: JML MU

Sumber : Data Diolah SPSS 21.0 (2019)

Koefisien determinasi (R2) pada dasarnya mengukur seberapa besar kemampuan model untuk menjelaskan variasi variabel dependen. Ghozali (2009) mengatakan bahwa koefisien determinasi adalah antara nol dan satu. Nilai R2 yang kecil berarti kemampuan variabel independen untuk menjelaskan variasi variabel dependen sangat terbatas. Nilai mendekati satu berarti bahwa variabel independen menyediakan hampir semua informasi yang diperlukan untuk memprediksi variasi variabel dependen (Ghozali, 2009). Pada penelitian ini diperoleh nilai adjusted R Square sebesar 0,415. Dengan demikian dapat disimpulkan bahwa variabel pengalaman merek, keterkaitan emosional pada merek dan citra merek terhadap niat memesan kembali Grab di Surabaya sebesar $41,5 \%$ dan selebihnya dijelaskan oleh faktor lain yang tidak dijelaskan dalam model regresi yang diperoleh.

\section{KESIMPULAN}

Hasil penelitian ini menunjukkan bahwa secara umum pengalaman merek dan keterkaitan emosional pada merek terhadap niat memesan kembali yang ada sudah baik. Hal ini ditunjukkan dari banyaknya tanggapan baik responden terhadap masing-masing variabel penelitian. Namun citra merek terhadap niat memesan kembali tidak menunjukkan tingkat signifikan yang memadahi. Hal ini pula ditunjukkan oleh hasil responden bahwa responden tidak hanya memilih Grab untuk memesan kembali apabila keadaan yang mendesak. Responden dalam keadan yang genting terkadang tidak melihat citra merek dalam memesan jasa transportasi online. Penelitian ini mengambil sampel responden sebanyak 150 orang yang pernah memakai jasa transportasi online Grab di surabaya. Tidak semua hipotesis di dalam penelitian ini dapat diterima. Dari ketiga variabel memiliki pengaruh paling tinggi adalah keterkaitan emosional pada merek, kemudian diikuti oleh pengalaman merek dan citra merek. Didalam penelitian ini variabel terikat (minat memesan kembali) dapat dijelaskan oleh variabel bebas (pengalaman merek, keterkaitan emosional pada merek dan citra merek) sebesar 41,5\% dan 58,5\% dijelaskan variabel bebas diluar penelitian ini.

\section{DAFTAR PUSTAKA}

Basrah Saidani dan Samsul Arifin. 2012. Pengaruh Kualitas Produk dan Kualitas Layanan Terhadap Kepuasan Konsumen dan Minat Beli Pada Ranch market. Jurnal Riset Manajemen Sains Indonesia No. 1 Vol 3 Hal. 1-22

Brakus, J.J., B.H. Schmitt, dan Zarantonello, L. (2009). Brand Experience: What Is It? How Is It Measured? Does It Affect Loyalty? Journal of Marketing, 73: 52-68.

Chinomona. R, (2013). "The Influence Of Brand Experience On Brand Satisfaction, Trust and Attachment In South Africa". Vol.12, No.10. 
Hair, J.F. JR., Anderson, R.E, Tatham, R.L. \& Black, W.C. (2006). Multivariate Data Analysis. Six Edition. New Jersey : Pearson Educational, Inc.

Kotler dan Keller. (2012). Manajemen Pemasaran edisi ketigabelas jilid 1 dan 2 dialihbahasakan oleh Bob Sabran, Jakarta: Erlangga.

Nugroho, setiadi J, 2003, perilaku konsumen : konsep dan implikasi untuk strategi dan penelitian bisnis pemasaran, Prenada Media, Jakarta.

Nurhayati, dan Wahyu, W. M. 2012. Analisis Faktor-Faktor Yang Memprngaruhi Minat Beli Ulang Masyarakat Terhadap Produk Handphone. Value Added: Vol 8, No 2. Universitas Muhammadiyah Semarang.

Ouwersloot, Hans dan Tudorica Anamaria. 2001. Brand Personality Creation through Advertising, Maastrich academic Center for Research in Services Journal.

Polancik, Gregor. (2009). Empirical Research Method Poster. Jakarta.

Priyatno, Duwi. (2012). Cara Kilat Belajar Analisis Data dengan SPSS 20, Yogyakarta, Penerbit Andi.

Sugiyono. (2009). Metode Penelitian Pendidikan Kuantitatif dan Kualitatif. Bandung : CV. Alfabeta

Thomson, M., D.J. MacInnis, dan C.W. Park (2005). The Ties That Bind: Measuring the Strength of Consumers' Emotional Attachments to Brands. Journal of Consumer Psychology, 15: 77-91. 